\title{
CHANGES IN CROSS-BORDER TOURIST TRAFFIC ON THE POLAND-BELARUS BORDER, AS EXEMPLIFIED BY THE AUGUSTÓW CANAL
}

\author{
Aliaksandr Cyargeenka ${ }^{a}$ iD \\ a Stanisław Leszczycki Institute of Geography and Spatial Organization Polish Academy of Sciences, Department of Urban and \\ Population Studies; https://orcid.org/0000-0002-9714-4128; e-mail: aliaksandrc@twarda.pan.pl
}

\begin{abstract}
The Augustów Canal is one of the unique tourist attractions of a Poland-Belarus borderland known for its highly valuable natural, cultural-historical and tourism-related features. From the beginning of the $21^{\text {st }}$ century, following total renovation as well as the opening of both water and road versions of the Rudawka-Lesnaya border crossing (in 2005 and 2017 respectively), it has been possible to observe a many-fold increase in tourist traffic within the Augustów Canal tourist space. The present article thus helps fill a research gap with an up-to-date description of this intensification and an analysis of its dynamics in terms of the countries of origin of visiting tourists, its seasonality and choice of transport, be it by water (by boat) or by road (by bicycle or on foot). This study continues investigations into the influence of the easing of the border regime in Belarus (introduction of a visa-free zone) on the volume of tourist traffic. Factors influencing cross-border traffic on the Augustów Canal have been studied at local, regional, national and international levels (multi-scalar). Fieldwork has also been organised, using the participant-observer method, and statistical data from the Polish Border Guard has been analysed. Results confirm that the greatest use made of the Rudawka-Lesnaya crossing is by tourists from Poland and Belarus, with smaller numbers from Lithuania, Russia and Germany. Poles are the nation most often availing themselves of opportunities to cross the border by water, while Belarusians show a preference for the road crossing.
\end{abstract}

\section{KEYWORDS}

Augustów Canal, border traffic, visa-free zone, tourism, Poland, Belarus

\section{ARTICLE INFORMATION DETAILS}

Received:

13 January 2021

Accepted:

11 May 2021

Published:

25 June 2021

This article includes the results of research carried out within the framework of a project entitled "Polish borders as a resource - between heritage and tourist product", funded by Poland's National Science Centre and assigned the number 2018/29/B/ HS4/02417.

\section{INTRODUCTION}

"Canal" is a term used for an artificial watercourse, and thus a type of inland waterway, perhaps as a canalised river or lake, or else purpose-built. Typically, canals serve to link drainage basins, in this way lowering transport costs and/or facilitating the transport of goods (cargo) and people (passengers). The Augustów Canal under study here likewise served such functions, while more recently as a tourist attraction located in the Augustów Forest, an area of exceptional natural value (Around Augustów Canal, 2018; Pogranicze..., 2018).
The Augustów Canal is described by researchers as a "phenomenon" when set against other hydrotechnical monuments, above all reflecting the way in which this is the only artificial waterway crossing the eastern external frontier of the European Union (in the borderland region of Poland and Belarus, as well as parts of Lithuania), forming a unique cultural and natural borderland area which is of steadily-growing significance to tourism (Cyargeenka, Więckowski, 2020; Marin, 2017; Sialverstava, Bogusz and Roman, 2018). The functioning of this system with its features of transboundary tourist space is dependent on many 
factors including those relating to the river network, nature conservation, transport and the geopolitical relations between the states involved (Kałuski, 2016). A condition for the development of the tourist function in the Augustów Canal area is the establishment, promotion and diversification of the tourist product on the basis of local spatial and natural resources, and the shared culture and history of neighbouring states (Bogusz, Sialverstava, 2018; Kul-Sialverstava, 2014).

The area "hydronode" of the Augustów Canal mostly draws tourists from Poland, Belarus and Lithuania and constitutes an element of cross-border tourism of a "sentimental" nature back to the time when Polish lands once extended beyond today's border. The canal serves as a kind of backbone, around which many items of cultural heritage are situated (Lenart, 2008; Sialverstava, Bogusz, 2018). Furthermore, this area is perceived to be one of the possible "bridges" to transboundary and cross-border cooperation in the name of environmental protection and the development of ecotourism, and this has become a reality on local, regional, national and international levels (Marin, 2011, 2017).

State borders offer a reflection of relations between neighbours, with a changing mix of conflict, competition, subordination and cooperation, as well as different aspects relating to how the border is viewed and perceived (Kolosov, Więckowski, 2018). The Augustów Canal is a good subject with which to study the ever-changing cross-border socioeconomic and political processes of both an integrative and disintegrative nature (Cyargeenka, Więckowski, 2020; Marin, 2017). In its original period (1820-1840), it served as a transport artery linking the western borderland of the Russian Empire with the Baltic Sea. However, it rather soon lost its main economic significance, while from the Second World War onwards found itself in two different states, i.e. Poland and the USSR. However, from the 1970s on the Polish side, and from the beginning of the $21^{\text {st }}$ century in the Poland-Belarus borderland area, the Augustów Canal has steadily taken on the features of a key element of tourism space with canoeing and kayaking dynamically developing along with other forms of active tourism (Cudowski and Górniak, 2008).

Research into the kinds of visitors and their motivations, combines with consideration of the means of crossing to highlight organisational, financial and psychological issues capable of either retarding or accelerating tourism within the Augustów Canal space (Bobowska, 2018; Yeliseyeu, 2017). An exceptional aspect is the introduction and extension of a visa-free border zone for visits into Belarus made available to citizens of around 70 states, brought into effect in 2015-2016 but facing many challenges currently (Kudžmaitė, 2019; Więckowski, Cyargeenka, 2019). The subject literature lacks both up-to-date research on the Augustów Canal space in terms of the circumstances leading to the intensification of cross-border tourist traffic, and analyses founded on primary statistical data (only appearing relatively recently). This article and the work underpinning it have thus been intended to fill this research gap.

Against this background, the investigation described here has above all sought to identify the changes along or adjacent to the Augustów Canal and the factors operating on these changes relating to the nature of cross-border tourist traffic, by reference to statistical data from the Rudawka-Lesnaya border crossing between Poland and Belarus. In essence, the research hypothesis advanced here is that the establishment and then expansion of the Belarusian visa-free travel zone involving the Augustów Canal "Tourist and Recreational Park", together with the introduction of the opportunity to cross the border on foot or by bicycle, has exerted a positive influence in increasing tourism for the citizens of both Poland and Belarus.

\section{RESEARCH METHODS}

This is a study of both a descriptive and an analytical nature. In the first stage, a search through the entire current literature was made in order to determine what the relevant cultural-historical, institutional and infrastructural, formal-legal and other conditions might be. As the analysis of factors impacting on cross-border tourist traffic involving the Augustów Canal was pursued on local, regional, national and international levels, a multi-scalar approach can be said to have been taken (Marin, 2011; Stoffelen, Ioannides, Vanneste, 2017).

In July 2019 fieldwork was organised as an opportunity to apply the participant-observer method with the border being crossed at Rudawka-Lesnaya on foot, and with a visit made to the Kurzyniec and Valkushyk Locks (in Poland and Belarus respectively). The process of crossing the border comprised the three stages of "before", "during" and "after" (Kudžmaitè, 2019; Zichner, Beurskens, Miggelbrink, Bruns, 2017). Prior to travel, information was gathered on visa and visa-free regimes and opportunities to hire a canoe/ kayak or bicycle; while the necessary documents were also being made ready. During the stay on the Polish side of the border, on the border itself, and beyond it, fieldwork sought to check procedures, times taken, accessibility, and the state and adequacy of signposting and the marking of infrastructure. Photographs were also taken.

Use was furthermore made of statistical analysis with regard to types and changes of tourist traffic, relating to the different countries of origin of tourists, the seasonality of tourism, and preferences shown for 
modes of travel: by water (by boat) or by road (by bicycle or on foot). Source data here originate from the reports of the Polish Border Guard, and relate to traffic across the Polish border involving individuals. Methods of both selection and systematisation were applied to all of the data on crossings, countries of origin and length of stay. Results were generalised in the form of tables and diagrams, with the most important trends indicated.

\section{THE Augustów CANAL AS THE MAIN ELEMENT OF TOURISM SPACE}

This article features an analysis concerning tourist traffic via the Rudawka-Lesnaya border crossing in the context of tourism space and with account taken of local, regional and international levels. The concept of tourism space is in fact understood rather differently by researchers around the world on the one hand, and by those in Poland on the other. The most frequent definition relates to the consequences of the overlap of selected geographical spaces. In turn, from the work of Kowalczyk (2014) is the idea that tourism space is simultaneously both an objective and a subjective category, and one which exists in four forms traditionally encapsulated as "space of the tourist", "space of tourists", "tourism space" and (most appropriately) "tourist space". Indeed, the relevant issues of delimitation and classification have, among others, been taken up by Włodarczyk (2014) who defines it as that part of geographical space in which tourism takes place. The space associated with the Augustów Canal has certain features of a subecumene where tourism is concerned. Given the nature of its (real, landscape related, riparian-lacustrine) attributes or its tourism management (related to recreation and sport), it supports tourism characterised by seasonality, lack of continuity and sporadicity (Więckowski, 2014; Włodarczyk, 2014).

The Augustów Canal sensu stricto is a water axis as well as a "backbone" linking two separate (Polish and Belarusian) transboundary tourism spaces. The Augustów Forest region as conceived in its broader sense (together with Augustów itself and Grodno/ Hrodna) constitutes a tourism space sensu largo. Most of the forest and canal are located on the Polish side and lies adjacent to Wigierski (Lake Wigry) National Park to the north west and the Biebrzański National park to the south. Within the forest there are also four Areas of Protected Landscape (Augustów Forest and Lakes, Rospuda Valley, Sejny Lakeland and the Biebrza Valley). There are a large number of nature reserves here (Perkuć, Brzozowy Grąd and so on). In contrast, on the Belarusian side the canal area includes the Sapotskin and Hoža Reserves, the Porzecze Botanical Reserve,
Sviatsk Landscape Park and the Landscape and Nature Park in Radzivilki (Kopciała, 2000b; Pozlevich, 2016). To the north-east, the Augustów Forest also links up with Lithuania's Kapčiamiestis and Dainava Forests.

The Augustów Canal tourism space is of interest to visitors as relatively primordial (natural), but also on account of its anthropogenic space within historical times. Specifically, the canal was constructed between 1824 and 1839 on the territory of the Kingdom of Poland, which then formed part of the Russian Empire (Romanowa, Szirokowa, Ozierowa, Czesnow, Sobisiewicz, 2018). The main reason for its construction was a "customs war" with Prussia that resulted in a many-fold increase in the fees needing to be paid for Polish grain to be transferred to Gdańsk (Górewicz, Orłowski, 1973). The canal was designed in such a way as to link the basins of the rivers Vistula and Nieman, as well as the Nieman and the Venta (via the Windawski Canal), making it possible for the Baltic to be accessed via the region of Livonia (known as Inflanty in Polish).

Only the first part of the plan was actually put into effect, and this was for several reasons. In the first place, once work on building the Augustów Canal had begun, Prussia had little choice but to reduce the duties imposed in order to avoid losses (Górewicz, 1974). In the second place, Poland's November Rising of 1830-1831 stood in the way of further work (Rutkowski, 2017), with the Tsarist authorities coming to see the idea of building the Windawski Canal as unnecessary. This ensured a downgrading of the Augustów Canal, in existence already by then, to the role of local transport involving what is today the borderland between Poland, Belarus and Lithuania. The main use of the Augustów Canal was as a way of transporting salt from Poland to Lithuania and Belarus; while the whole period through to the 1970s saw it as a route for the floating of timber. Nevertheless, by 1860-1880, the rapid development of railways was already reducing the significance of the canal in transport terms, and more generally from an economic point of view.

The Augustów Canal tourism space also catches the interest of tourists on account of the cultural (and especially the hydrotechnical) heritage that is present here. The canal features 18 locks (with a total of 21 chambers), 14 of these in Poland, three in Belarus with one actually on the border. Among these, there are nine in Poland, three in Belarus plus the one on the border itself that retain their original structure from the first half of the $19^{\text {th }}$ century. In fact only the facing has changed (Batura, 2005). The Augustów Canal differs from other similar constructions in its large dimensions (it is $101 \mathrm{~km}$ long), and the presence of a great many excavated sections, weirs and basins; as well as the absence of any disasters concerning leaks.

Thus the Augustów Canal has remained in an almost unchanged state since the time it was built, albeit this 
reflecting a dramatic decline in its economic significance. It is thus unique among European canals in never having undergone modernisation or remodelling (Górewicz, Orłowski, 1973). As early as 1968 it came to be recognised by Poland's Ministry of Culture and Art as a monument of engineering and architectural achievement, becoming a Historical Monument as such in 2007, with this representing a key factor in the development of the tourist space. In turn, in 2010, an application was submitted to UNESCO with a view to the canal being included on the World Heritage List (though it in fact failed to pass the verification procedure).

\section{CHANGES IN THE FUNCTIONS OF THE BORDER AND OPPORTUNITIES FOR CROSSING}

In the days of the Russian Empire, the Augustów Canal was not divided by a border, and the Kingdom of Poland had a measure of administrative autonomy. It was even, back at that time, that the first opportunity for tourism to develop here began to emerge as 1909 brought the organisation of a hiking trip under the auspices of the sightseeing organisation Polskie Towarzystwo Krajoznawcze, taking in Augustów, Studzieniczna and Swoboda. Then in 1912 there was a combined walking and wagon trip following the "Napoleon Trail" from Suwałki via Wigry to Grodno and further on to Babruysk (Kopciała, 2000a).

In the inter-war period, the whole of the Augustów Canal was again contained within a single polity at state-level; a fact that helped dynamise the development of canoeing with the encouragement of Polish Scouts. The canal also attracted the interest of the Polish Canoeing Union (Polski Zwiazek Kajakowy), the Officers' Yacht Club of the Republic of Poland, the State Water Board (Państwowy Zarzad Wodny), and also private enterprises offering cruises whereby barges with passengers were towed (both Augustów and Grodno being linked regularly in this way). In addition, there was an intensive development of health-resort tourism. Thus, the Augustów Canal area had started to take on the features of genuine tourism space.

In the years 1945-1989, the tourism area of the Augustów Canal was of course divided between the Polish People's Republic and the USSR. Despite the countries being ostensibly friendly, the actual effect was for tourism to vanish from this region for two reasons. In the first place, the state border was treated very inflexibly, and in the second there had been serious destruction or damage by this time to the hydrotechnical infrastructure.

However, from the 1970s onwards, the Polish side witnessed a renewed period of tourist activation along the canal, even as the Soviet (Belarusian) side was totally neglected. The 1989-2007 period coincided with a facilitated process for crossing the border, as the visa regime was at last lifted in reality. Yet this situation reversed again thanks to events in 2004 and 2007: Poland's accession to the EU and then to the Schengen Zone. The result was an emergence of a closed external European Union frontier, with border checks very much strengthened, and it once again became difficult to cross in either direction (Więckowski, 2010b).

From the time of Poland's Schengen accession (i.e. from 2007), the cost of the visa needed by Belarusians was 60 euros. But from the time when the EU Visa Code came into force (i.e. 2.02.2020), that price had increased to 80 euros, even though half a year later (on 1.07.2020) it was to cost just 35 euros. What is more, through to January 2019, there was a chance to obtain a so-called shopping visa (of short duration and without any extra formalities), and rather wide use was made of this by Belarusians for tourist purposes. On $22^{\text {nd }}$ September 2020, the Polish government reversed the earlier (late-March) closure of the border on account of the COVID-19 pandemic, making it possible once again for Belarusians to pay tourism-motivated visits to Poland. From October 29th 2020, crossing from Poland to the territory of Belarus via road was again suspended, the decision on this occasion being made by Belarus.

A Belarusian visa for Polish (and other EU) citizens has recently been priced in the range 20-120 euros (currently 35 and 75). The decisive factors here are the type (private, service-related, tourist, etc.), length of stay, number of visits anticipated, the ways in which this visa is granted and delivered (with a wait of between 2 and 10 working days), and the potential commission that travel agents are likely to take. Visa applications may be submitted in Warsaw, Biała Podlaska and Białystok. However, in the 2007-2010 period, there was also the seasonal opening of a Consular Office in Augustów itself. Ultimately, this closed down in the face of the rather low number of tourist visas actually being issued.

A unique phenomenon in terms of the easing or relaxation of the ways in which the border might be crossed was the introduction of a so-called visa-free zone for Belarus in the shared borderland area with Poland, and also in part in Lithuania (Więckowski, Cyargeenka, 2019). The process was first trialled in the Belovezhskaya Pushcha National Park (adjacent to Poland's Białowieża NP) in 2015, with it becoming possible to take a trip into the Belarusian part of the same forest on foot or by bicycle via the Białowieża-Pierarova crossing. In the case of the Augustów Canal, a similar zone of visa-free travel, within what was identified as a 'Tourist and Recreational Park' associated with the canal, began to operate from October $26^{\text {th }} 2016$, by virtue of Decree No. 318, whose provisions related not only to the canal itself, but also to the city of Grodno (Table 1). 
Table 1. Transboundary visa-free traffic in the Augustów Canal region

\begin{tabular}{|l|l|l|l|}
\hline $\begin{array}{l}\text { Borderland } \\
\text { visa-free } \\
\text { zone }\end{array}$ & \multicolumn{2}{|c|}{ Augustów Canal Tourist and Recreational Park } & \multicolumn{1}{c|}{ Brest-Grodno visa-free zone } \\
\hline $\begin{array}{l}\text { Date } \\
\text { of opening }\end{array}$ & 26.10 .2016 & 1.01 .2018 & 10.11 .2019 \\
\hline $\begin{array}{l}\text { Length } \\
\text { of stay }\end{array}$ & up to 5 days & up to 10 days & up to 15 days \\
\hline $\begin{array}{l}\text { Area } \\
\text { accessible } \\
\text { to visa-free } \\
\text { traffic }\end{array}$ & $\begin{array}{l}\text { The city of Grodno, } \\
\text { plus the districts } \\
\text { (selsoviets) of Hoža, } \\
\text { Kapciouka, Odelsk, } \\
\text { Padlabiennie } \\
\text { and Sapotskin }\end{array}$ & $\begin{array}{l}\text { City of Grodno } \\
\text { and Hrodna District }\end{array}$ & $\begin{array}{l}\text { The city of Grodno and Districts of Grodno, Bierastavica, } \\
\text { Vawkawysk, Voranava, Lida and Svislach; } \\
\text { the city of Brest and Districts of Brest, Zhabinka, } \\
\text { Kamyanyets and Pruzhany }\end{array}$ \\
\hline $\begin{array}{l}\text { Border } \\
\text { Crossings } \\
\text { open for } \\
\text { visa-free } \\
\text { traffic }\end{array}$ & $\begin{array}{l}\text { Rudawka-Lesnaya (PL-BY), } \\
\text { Kuźnica Białostocka- } \\
\text { Bruzgi (PL-BY), } \\
\text { Privalka-Švendubre (BY-LT) } \\
\text { and Privalka-Raigardas } \\
\text { (BY-LT) }\end{array}$ & $\begin{array}{l}\text { Kuźnica Białostocka- } \\
\text { Grodno (PL-BY), } \\
\text { Grodno Airport (BY) }\end{array}$ & $\begin{array}{l}\text { Białowieża-Pierarova (PL-BY), Byenyakoni- } \\
\text { Shalchininkai (BY-LT), Bobrowniki-Bierastavica } \\
\text { (PL-BY), Połowce-Peschatka (PL-BY), Sławatycze- } \\
\text { Domachewo (PL-BY), Terespol-Brest (PL-BY) } \\
\text { and Brest Airport (BY) }\end{array}$ \\
\hline
\end{tabular}

Legend: BY - Belarus, LT - Lithuania, PL - Poland, RU - Russia, UA - Ukraine.

Source: author.

The privilege associated with a visa-free trip into the near-border area of Belarus applies to citizens of some 70 states, including Poland, Lithuania, Latvia, Germany and the USA. For a crossing of the border to take place, the essential documents are:

- a valid passport,

- insurance (medical, as well as the so-called 'Green Card' if the crossing is being made by car),

- a permit (issued by an authorised tourist operator),

- purchased entry tickets to at least two tourist attractions in Belarus,

- confirmation of reserved places in overnight accommodation (where the stay is to exceed 10 days). The territorial cohesion of the Belarusian visa-free zone and the tourism space steadily taking shape have both encouraged visitors to make a longer stay and thus to visit not only the Augustów Canal itself, but also Grodno and its surroundings including the Royal Castle and the Orthodox Church in Kalozha, places associated with the life of the Polish novelist Eliza Orzeszkowa, bunkers along the Molotov Line, and the palace-park complex of the Wołłowicz family at Sviatsk. These sites (mainly of a military, religious, cultural-historical or natural profile) represent the shared heritage of the old Polish Commonwealth and are thus an objective for sentimentally motivated travel on the part of both Poles and Lithuanians (Otwierajac białoruskie pogranicze..., 2018). The chance to travel visa-free through western Belarus makes possible visits to three out of four of the UNESCO World Heritage sites listed for Belarus (i.e. along the Struve Geodetic Arc, the castle in Mir, and Belovezhskaya Pushcha - the area of forest across the border from Poland's Białowieża NP), along with a number of cultural and historical monuments present in Brest, Lida and Navahrudak.

The consequence of the opening-up of the border is the appearance of many routes to enter the Belarusian visa-free zone (including the tourism space along the Augustów Canal). In total, there are 14 border crossings, and many means by which they can be crossed, not least by canoe or kayak, or bicycle, on foot, by car or coach, and by train or aircraft. At present, tourists may cross into Belarus for a period as long as 15 days via the Rudawka-Lesnaya crossing, visit Grodno, but then leave via the Terespol-Brest and BiałowieżaPierarova crossings, or else by canoe into Lithuania via the Privalka-Svendubre crossing. In the case of Rudawka-Lesnaya, however, the inclusion of certain options looks debatable as, for example, there are no permanent connections by plane between Poland and either Grodno or Brest. There are also other problems in organising visits: difficulties with the hiring and also leaving of canoes or bicycles on the opposite side of the border, limits on public-transport (coach or train) accessibility, and further limits on physical opportunities available to tourists.

\section{TRANSBOUNDARY OR CROSS-BORDER STATUS AND THE LEVEL OF PREPARATION OF TOURISM SPACE}

A further important element of tourism space is the matter of the delimitation of the functional sub-region of cross-border cooperation defined by researchers 
as Puszcza Augustowska, i.e. Augustów Forest (Suliga, 1996), the Białystok-Grodno region (Eberhardt, 1996) or the Augustów-Grodno Forest area (Roman, Sawośko, Żendzian, Niesteruk, 2018) (Fig. 1). A key question relating to studies of cross-border tourist traffic is whether account is taken of the immediate vicinity of the forest only, or a more extensive tourism space taking in the cities of Białystok (Poland), Grodno (Belarus), or even Druskininkai (Lithuania). From 1997 on the Augustów Canal area came within the Niemen Euroregion and included the border area of Poland's Podlaskie voivodeship, the Grodno/Hrodna District of Belarus in its entirety, and certain local government areas in Lithuania and the Russian Federation's Kaliningrad District (Kowalewska, Słoma, 2015). Such peripheral transboundary euroregions associated with the River Niemen (Neman), but also with the Białowieska/Belovezhskaya Forest (Poland and Belarus) and the River Bug (Poland, Belarus and Ukraine) form key areas for green or ecotourism, as well as tourism falling within cultural and nostalgic categories (Marin, 2017).
Beyond even that, the years since 2007 have seen Belarus join five other countries within the Eastern Partnership of the EU and as a part of the European Neighbourhood and Partnership Instrument within the framework of the Poland-Belarus-Ukraine and Latvia-Lithuania-Belarus Transboundary Cooperation Programmes. These are addressed to such matters as environmental protection, tourism, cross-border security and cross-border contacts between local social and economic centres. Nevertheless, given the geographical locations characterising both Ukraine and Latvia (and even Lithuania to a lesser degree), issues relating to the Augustów Canal are only of secondary importance.

The small-scale local border links developed on the basis of three separate agreements that Belarus concluded in 2010 with Poland, Lithuania and Latvia respectively were capable of favouring increased tourism traffic. However, it was only in fact with Latvia in 2012 that an agreement actually entered into force. And it was mainly for economic reasons that Belarus ultimately said no to the enactment of Local Border

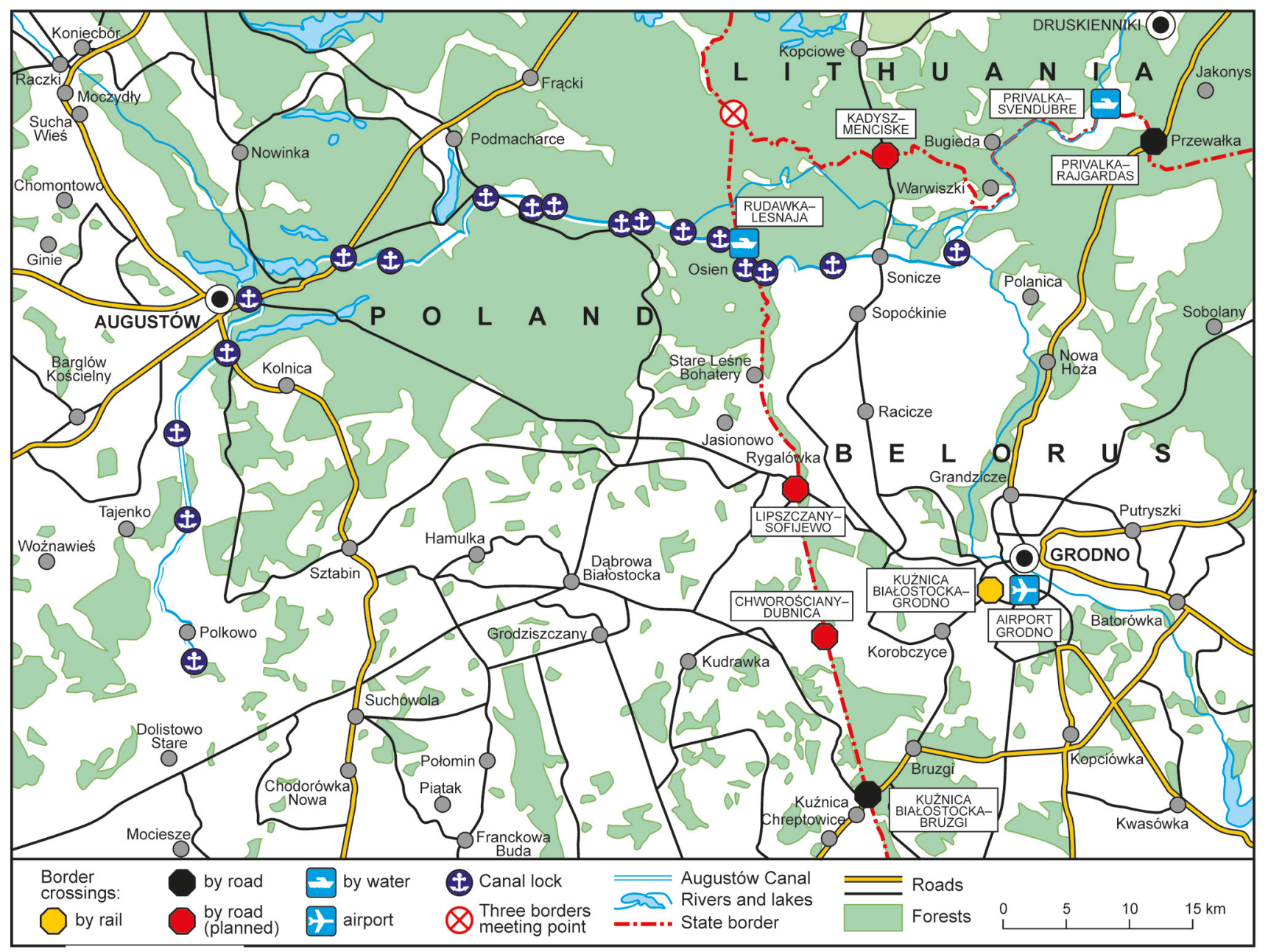

Figure 1. Location of the Augustów Canal Source: author 
Traffic agreements with Poland and Lithuania; its fear being simply that around 1.5 million Belarusians would avail themselves of an opportunity to do lower-cost shopping in the neighbouring countries (Yeliseyeu, 2017).

\section{FACTORS INFLUENCING LOCAL TOURIST TRAFFIC}

The most important events exerting a major impact on the Augustów Canal tourism space should include the 2005 opening of a water Poland-Belarus border crossing located at Kurzyniec Lock (Photo 1). In 2004-2006 there was a general renovation of the canal's locks, weirs and basins on both the Belarusian and Polish sides. Furthermore, removal of a meander, enhanced erosion and a lowering of the water table (to about $1.4 \mathrm{~m}$ ) changed the channel of the Nieman, giving rise to a fourth (additional) chamber for Nemnovo Lock (Ber, Graniczny, Kowalski, Marks, Urban, 2007).

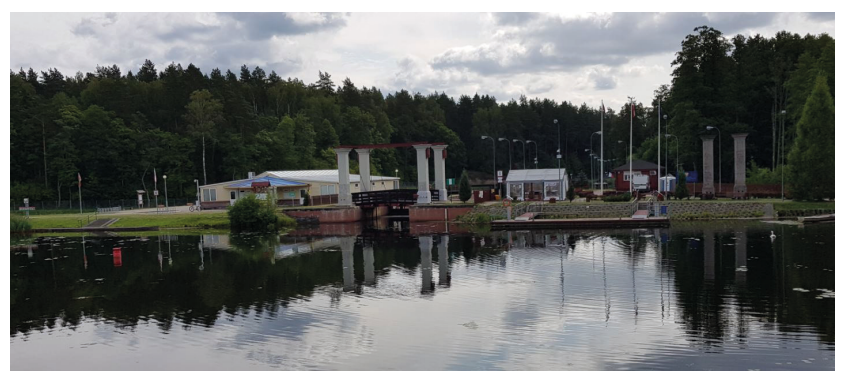

Photo 1. Kurzyniec Lock on the Augustów Canal at the PolishBelarusian Rudawka-Lesnaya border crossing Source: Marek Więckowski (July 2019)

A further stimulus to the development of local tourist traffic came with Belarus's October 2016 introduction of a visa-free regime for access to the Augustów Canal 'Tourist and Recreational Park'. This decision was followed by steady increases in the size of the visafree zone and the Augustów Canal tourist space, as well as in the numbers of border crossings serving visa-free movement, and lengths of stay. Successive enlargements of the zone and increases in the numbers of crossings made in the visa-free context (between Belarus and both Poland and Lithuania) took place on January $1^{\text {st }} 2018$ and November $10^{\text {th }} 2019$ (Bobowska, 2018; Więckowski, Cyargeenka, 2019) (Table 1).

It is worth stressing the benefits for the Augustów Canal region accruing from the use of EU funding to redevelop cross-border tourist infrastructure involving repair work and the building of a new network of roads. However, some of this activity failed to pay heed to the lack of cohesion of the transboundary tourist space. It has been typical for local roads in Belarus, Poland and Lithuania to be modernised entirely in isolation of each other, with no account therefore taken of the overall transport situation. There are also cases of "roads to nowhere" being built, in the sense that these lead towards a stretch of the border not equipped with any crossing. For example, in 2014 work was done on the H-6049 Ratichi-Polnyje Bogatyri motorway in Belarus, as well as provincial road no. 664 in Poland, with the intention to link the Belarusian part of the Augustów Canal and the city of Grodno to Augustów. It was not achieved, given the non-appearance of the planned road crossing at Lipszczany-Sofievo. A similar situation was found at the Kadysh-Menciške crossing on the BelarusLithuania border.

A major hindrance to the process by which border traffic at a local level is increased comes with the dilemma over whether to protect the environment or further develop infrastructure. On the one hand, the transboundary status of Augustów Forest ensures the presence throughout this region of protected areas that do not allow infrastructure (even for tourism) to develop, or at most permit it to do so only to a very limited extent (hence the major conflict surrounding construction of the Augustów Bypass in the years 2007-2009). On the other hand, the development of infrastructure in the Augustów Canal area (taking the form of roads, transport links, cycle trails, walking trails, cross-border tourist trails, routes along inland waterways, viewing towers, local border crossings and so on) was what made possible the further development of tourism (and the growth of tourist traffic) in this area (Więckowski, 2010a).

\section{ChANGES IN TOURIST TRAFFIC EXEMPLIFIED BY THE RUdAWKA-LESNAYA BORDER CROSSING}

Analysis of individual-level tourist traffic at the Rudawka-Lesnaya Crossing gave rise to the separate identification of three periods of operation (Fig. 2). The first, encompassing 2005-2016, had a low intensity, as well as a clear disproportion between numbers of people leaving and arriving (in line with their citizenship). Then, in the first years following opening of the crossing, very many more left Poland than arrived. Indeed, in 2005, 16-times more people left for Belarus than travelled into Poland, while the equivalent 2016 disparity was a mere 1.6-times. However, the scale of this traffic is found to be minimal in absolute terms. The highest figure travelling out of Poland was 275 in 2010, while the most coming in was 175 in 2012. The minima (10 people in each case) were found in 2005 (arrivals) and 2006 (arrivals and departures).

The second period encompasses the years 2017-2019 and is characterised by an abrupt increase in individual traffic. In 2017 compared with 2016, the numbers crossing 


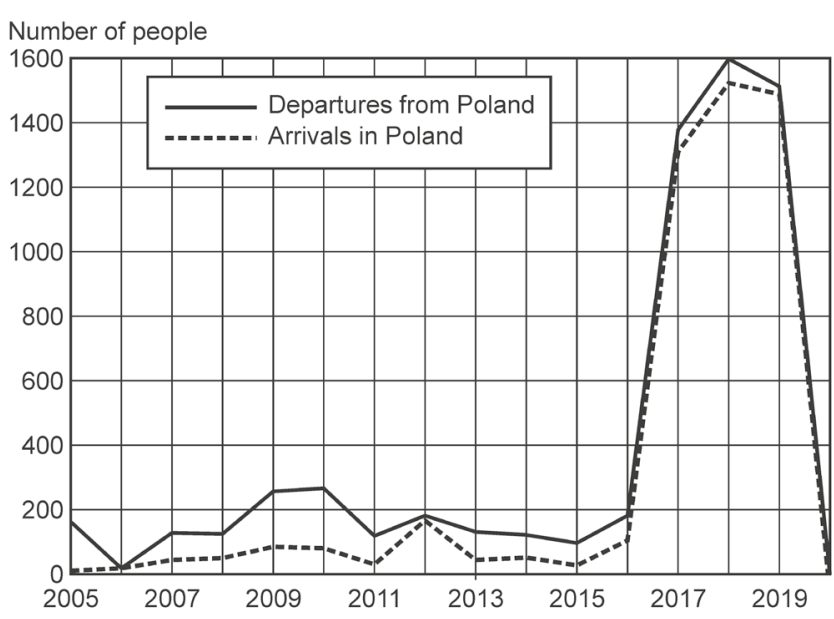

Figure 2. Numbers of people crossing the Poland-Belarus border at the Rudawka-Lesnaya crossing in 2005-2020

Source: author on the basis of data from Poland's Border Guard

over from Poland were more than eight times greater, while the numbers crossing into Poland were over twelve times greater. The peak was noted in 2018 when the border was crossed by 1615 people in the Belarusian direction and 1533 people in the Polish direction. The main cause of the increase was the introduction of visafree travel into border areas (especially the Augustów Canal and Grodno), as well as permitting crossing by bicycle or on foot. As a consequence of the political and administrative decisions, Poland's Green Velo Eastern Cycle Trail was extended into Belarus, taking the name of the August Velo Cross-Border Cycle Trail (Tourist Passport, 2018) (Photo 2).

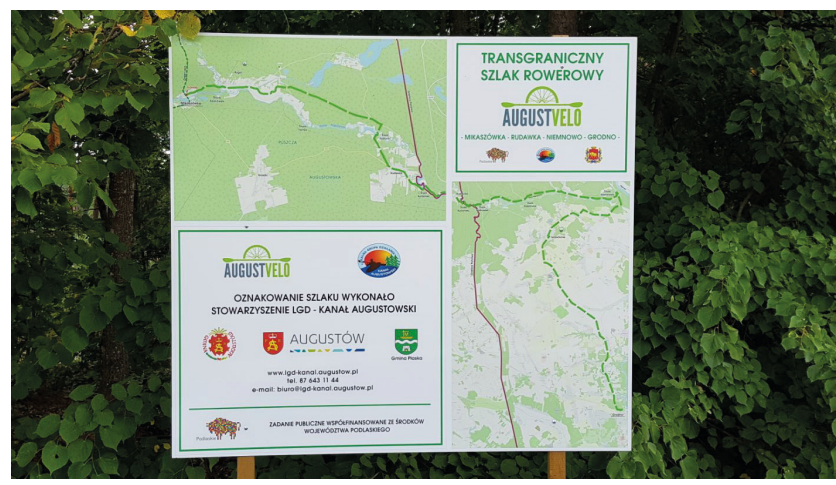

Photo 2. Information board with a map of the August Velo and Green Velo cross-border cycle trail which runs along the Mikaszówka-Rudawka-Nemnovo-Grodno route Source: Marek Więckowski (July 2019)

2019 brought a slight reduction in cross-border traffic. Those most interested in what was on offer here, above all visitors keen to travel by canoe or kayak or bicycle, or else participate in sentimental tourism and the like, had already taken advantage of the opportunities, and were not planning to make a return visit in the near future.
The latest period began in 2020, as the COVID-19 pandemic took hold and late March saw the crossing of the Poland-Belarus border limited to just the three border crossings that remained open (i.e. TerespolBrest, Kuźnica Białostocka-Bruzhi and BobrownikiBierastavica). The Rudawka-Lesnaya crossing was simply closed, ensuring that there was no border traffic at all here in 2020.

Where seasonality influences the rate of border traffic, it needs of course to be stressed how periodic the operations of this crossing are (indeed by definition). For opening here takes place in late April or early May and goes through only to the end of September or beginning of October (and then only in daylight hours). Furthermore, the 2005-2016 period was associated with what might be termed crossing at least in part "by appointment". Simply speaking, it is not always the case that customs officials are present, making it necessary for trips by water to be announced at least a day in advance, if a wait of several hours is to be avoided. Further obstacles to a smooth visit have related to the very low intensity of the traffic overall, as well as the renovation work done along the canal in 2005-2007. Information from the Border Guard reveals days, or even months, in which there was no border traffic at all. Equally, data from the years 2017-2019 make it quite clear that traffic is always heaviest in July.

Traffic at the Rudawka-Lesnaya Crossing is dominated by Poles (Fig. 3), whether it is departures or arrivals that are involved. However, exceptions were noted in 2010 and 2017, when more non-Poles came into Poland (Fig. 4). Unfortunately, detailed data on the nationalities of foreigners involved from 2005 to 2010 and in 2014 are lacking. Data from the Border Guard concerning 2011-2013 and 2015-2019 point to a considerable (80$90 \%)$ prevalence of Belarusians. Where other states are concerned, most are from Lithuania, Russia and Germany. In 2019, 53\% of those coming into Poland were Poles, while $37 \%$ were Belarusians, $3 \%$ Lithuanians,

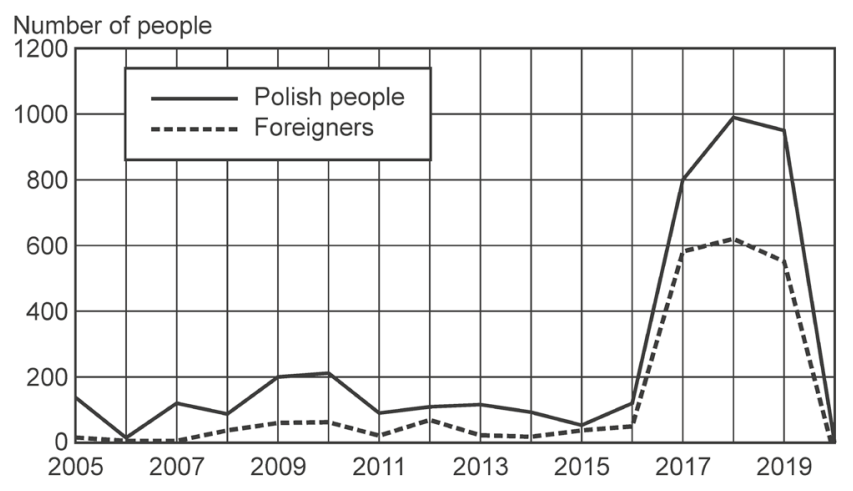

Figure 3. Numbers of Poles and foreigners travelling from Poland

via the Rudawka-Lesnaya border crossing in 2005-2020 Source: author based on data from the Polish Border Guard 


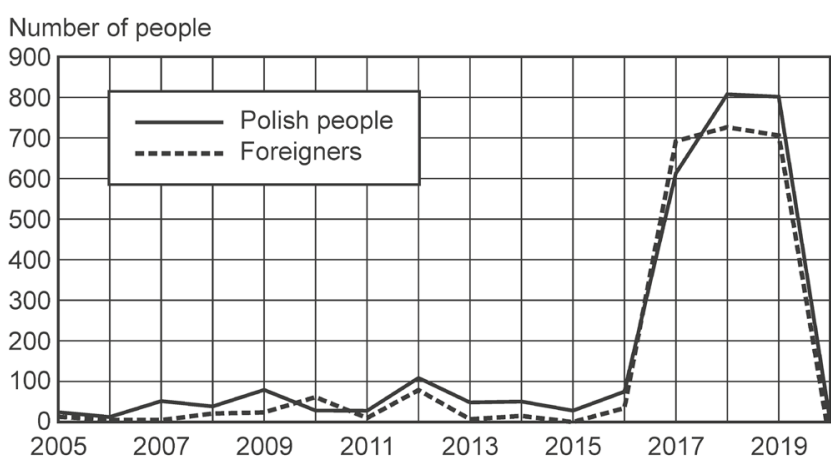

Figure 4. Numbers of Poles and foreigners crossing into Poland via the Rudawka-Lesnaya Border Crossing in 2005-2020

Source: author based on data from the Polish Border Guard

$3 \%$ Russians, 2\% Germans, and 2\% citizens of other countries. Among those travelling out of Poland, it was: Poles $-63 \%$, Belarusians $-32 \%$, Lithuanians $-2 \%$, Russians $-1 \%$, Germans $-1 \%$ and others $-1 \%$ (Table 2 ). It is thus clear how the factor of geography does much to influence division as regards origins of those crossing the border. Equally, sporadic cases involving travellers from distant countries are interesting, with the presence of the UK, Spain, the USA, Australia and China.

It is also worth noting differences between the numbers of given nationalities arriving and departing, especially among Poles and Belarusians. In 2019, around
150 (one-fifth) more Poles left than arrived, while 80 (almost one-fifth) fewer Belarusians left than arrived. This may reflect returns to the given country via a different border crossing, or else a longer stay in the country being visited.

Interesting results are also supplied by the analysis of border traffic in relation to the type of crossing made at the border (by road or water), as well as the citizenship of those travelling. As crossing the border on foot or by bicycle only became a reality from May 2017 onwards, the only data available are for 2017-2019 inclusive (Table 2). From these it can be learnt that:

- a higher (55-60\%) share of Poles leave Poland by means of transport on water than return in that way (the figure being around 35-40\%); (in contrast) fewer Belarusians (around 30\%) travel out of Poland by water than arrive into the country (around $70 \%)$

- where (by-bicycle or on-foot) use of the road crossing is concerned the departure-arrival difference is of the order of $1-2 \%$ for both Poles and Belarusians.

It needs to be stressed that just $10-20 \%$ of the Belarusians travelling from Poland chose water, while the proportions of those arriving fluctuated greatly over the three years (at 28\% in 2017, 43\% in 2018 and 16\% in 2019). Percentages of Poles taking the opportunity to cross the border by water are higher, and also less prone to fluctuation, with figures at $38-47 \%$ in relation

Table 2. Numbers crossing the border via the Rudawka-Lesnaya Crossing in 2017-2019:

by permanent place of residence, type of crossing and direction (departures from Poland and arrivals into Poland)

\begin{tabular}{|c|c|c|c|c|c|c|c|c|c|}
\hline Year & Direction & Type of crossing & Poland & Belarus & Lithuania & Germany & Russia & Other states & Total \\
\hline \multirow{6}{*}{2017} & \multirow{3}{*}{ departures } & road & 455 & 453 & 6 & 0 & 5 & 18 & 937 \\
\hline & & water & 343 & 54 & 28 & 14 & 0 & 8 & 447 \\
\hline & & total & 798 & 507 & 34 & 14 & 5 & 26 & 1384 \\
\hline & \multirow{3}{*}{ arrivals } & road & 416 & 450 & 9 & 2 & 10 & 19 & 906 \\
\hline & & water & 203 & 177 & 1 & 8 & 1 & 11 & 401 \\
\hline & & total & 619 & 627 & 10 & 10 & 11 & 30 & 1307 \\
\hline \multirow{6}{*}{2018} & \multirow{3}{*}{ departures } & road & 619 & 407 & 3 & 12 & 14 & 6 & 1061 \\
\hline & & water & 374 & 119 & 41 & 8 & 3 & 9 & 554 \\
\hline & & total & 993 & 526 & 44 & 20 & 17 & 15 & 1615 \\
\hline & \multirow{3}{*}{ arrivals } & road & 608 & 379 & 2 & 4 & 14 & 10 & 1017 \\
\hline & & water & 204 & 290 & 9 & 0 & 7 & 8 & 518 \\
\hline & & total & 812 & 669 & 11 & 4 & 21 & 18 & 1535 \\
\hline \multirow{6}{*}{2019} & \multirow{3}{*}{ departures } & road & 501 & 438 & 2 & 21 & 16 & 8 & 986 \\
\hline & & water & 452 & 38 & 14 & 4 & 3 & 11 & 522 \\
\hline & & total & 953 & 476 & 16 & 25 & 19 & 19 & 1508 \\
\hline & \multirow{3}{*}{ arrivals } & road & 502 & 471 & 31 & 20 & 39 & 29 & 1092 \\
\hline & & water & 298 & 87 & 14 & 2 & 10 & 2 & 413 \\
\hline & & total & 800 & 558 & 45 & 22 & 49 & 31 & 1505 \\
\hline
\end{tabular}

Source: author on the basis of data from the Polish Border Guard. 
to departures from Poland, as well as $25-37 \%$ when it comes to arrivals into Poland.

The following factors have been exerting an influence on the disproportions present between water and road traffic:

- a markedly better tourist infrastructure on the Polish side: an autonomous and many times larger base for water sports, with conditions more favourable when it comes to the hiring of boats of various kinds;

- a far weaker set of options in Belarus when it comes to hiring canoes, kayaks, pedalos, and so on, with this being confined in the sense of general access to the area around the Dambroŭka (Dambrowka) Lock jetty;

- a lack of opportunities for the state border to be crossed by a means of transport hired in Belarus (according to data collected from 10 Belarusian firms prior to the field trip);

- the ease with which the Augustów Canal can be travelled where people go with the flow in the Poland-Belarus direction and possibly on further via the Nieman into Lithuania, as opposed to going against the current;

- the presence of other border crossings via which people may enter into or exit from the Augustów Canal area.

\section{SUMMARY}

In summing up the work carried out it is possible to claim confirmation of the research hypothesis put forward at the outset. Thanks to the relaxation of the border regime for Belarus, as well as the steady expansion of the visa-free zone in the years 20152016, there was a marked increase in foreign tourist traffic at both the national level ${ }^{1}$, and local, i.e. in the Augustów Canal area. The increase in traffic along the canal route to the Rudawka-Lesnaya border crossing was also influenced by the introduction in 2017 of a way of crossing by road (although only on foot or by bicycle). The years 2017-2019 in fact represented the period of greatest enlivenment of tourist traffic using this crossing, especially when it came to citizens of states in the Niemen Euroregion, which is to say Poland, Belarus, Lithuania and Russia (with the first two clearly dominant, accounting for around $90 \%$ of the total). A preference for the water route was shown by Poles, even as Belarusians mainly opted for the road (on foot or by bicycle only). It was possible to note marked disproportions between arriving and departing tourists, with the details here found to depend on the direction of movement, country of origin, means of crossing and season of the year. There were days (and even whole weeks) when it was not possible to note any border traffic at all; as well as situations in which a given day saw a single-direction crossing by canoe or bicycle, or on foot, by several dozen citizens of Belarus, Poland and Lithuania, even if nobody went the opposite way (perhaps over the span of an entire week).

The opening up of the Rudawka-Lesnaya crossing along the Augustów Canal to individuals, combines with the access thereby granted to numerous (aquatic, natural and cultural-historical) attractions to generate, in and of itself, a basis for intensive development of tourism. The greatest potential for cross-border tourism is that offered by the Augustów Canal itself, in its role as an axis of cooperation. The most-advanced product here at present is provided by organised trips for active and specialised tourists along the canal, the product in question being a route or trail (i.e. level-II integration after Stasiak and Włodarczyk, 2008). However, it remains too soon to speak of the shaping of a transboundary tourist area. The positive trends of the past several years may weaken / stop due to a number of negative processes and phenomena. Equally, from 2020 on, traffic relating to the Augustów Canal has of course been influenced above all by a succession of pandemic-induced lockdowns announced as COVID spread. There is also the matter of the complex political situation in Belarus which led to a worsening of both Polish-Belarusian and Belarusian-EU relations, manifested even at the level of regional or local cooperation.

\section{ENDNOTE}

${ }^{1}$ In 2014, Belarus was visited by 1700 organised and oneday visits from Poland, as compared with around 6000 in 2015, around 8000 in 2016, 22,700 in 2017 and 46,300 in 2018 (Więckowski, Cyargeenka, 2019). Numbers of tourists and singleday visitors from Lithuania also increased from around 2000 in 2014 to 59,500 in 2018. However, the share of Lithuanians using the Rudawka-Lesnaya crossing has remained at the same $(1-3 \%)$ level for years now, possibly because of the location of the crossing in the Poland-Belarus borderland, the difficulties in canoeing against the current from Lithuania (via the Nieman and then the Augustów Canal), and the non-tourism-related (actually shopping-related) purposes associated with visits to Belarus by Lithuanians.

\section{REFERENCES}

Around Augustów Canal (2018). Białystok: Augustvelo.

Batura, W. (text), Mikos, M., Szlaszyński, J. (cooperation) (2005). Kanał Augustowski: wspólne dziedzictwo i przyszłość. Augustów: Zarząd Powiatu.

Ber, A., Graniczny, M., Kowalski, Z., Marks, L., Urban, H. (2007). Kanał Augustowski jako przykład dziedzictwa historycznego, 
technicznego i przyrodniczego [The Augustów Canal as an example of historical, technical and natural heritage]. Przeglad Geologiczny, 55 (9), 765-769.

Bobowska, M. (2018). Turystyka bezwizowa pomiędzy Polską a Białorusią z punktu widzenia studentów z miasta Białegostoku i okolic - korzyści oraz szanse. In: S. Sialverstava, A. Roman, J. Zuzda (eds), Promocja turystyki na pograniczu polsko-białoruskim (pp. 189-200). Białystok: Wydawnictwo Niepublicznej Placówki Doskonalenia Nauczycieli "Edukacja, Wychowanie i Bezpieczeństwo" przy Towarzystwie Zapobiegania Tonięciom i Ratowania Tonących w Białymstoku.

Bogusz, T., Sialverstava, S. (2018). Wielokulturowość polskobiałoruskiego pogranicza: aspekt turystyczny. In: S. Sialverstava, A. Roman, J. Zuzda (eds), Promocja turystyki na pograniczu polsko-białoruskim (pp. 69-78). Białystok: Wydawnictwo Niepublicznej Placówki Doskonalenia Nauczycieli „Edukacja, Wychowanie i Bezpieczeństwo” przy Towarzystwie Zapobiegania Tonięciom i Ratowania Tonących w Białymstoku.

Cudowski, A., Górniak, A. (2008). Przyrodnicze uwarunkowania funkcjonowania Kanału Augustowskiego i jego hydrochemia. In: E. Jekatierynczuk-Rudczyk, M. Stepaniuk (eds), Rozwój obszarów przyrodniczo cennych (pp. 165-176). Białystok: Oddział Białostocki Polskiego Towarzystwa Geograficznego.

Cyargeenka, A., Więckowski, M. (2020). Expanding transboundary tourist space - The growing significance of the Augustów Canal. Baltic Journal of Health and Physical Activity, 12 (Special Issue 1) 130-138. https://doi.org/10.29359/BJHPA.12.Spec.Iss1.15

Eberhardt, P. (1996). Propozycja wydzielenia regionów współpracy na wschodnim pograniczu Polski. In: A. Miszczuk, R. Wiśniewski (eds), Informacyjno-infrastrukturalne uwarunkowania wspótpracy transgranicznej. Vol. 2 (pp. 85-88). Lublin: Norbertinum.

Górewicz, J. (1974). Opowieść o Kanale Augustowskim. Warsaw: Wydawnictwo "Sport i turystyka”.

Górewicz, J., Orłowski, B. (1973). Kanat Augustowski: 150 lat. Augustów: Towarzystwo Miłośników Ziemi Augustowskiej.

Kałuski, S. (2016). Trójstyki granic politycznych. Zróżnicowanie cech i funkcji. Czasopismo Geograficzne, 87 (2), 101-115.

Kolosov, V., Więckowski, M. (2018), Border changes in Central and Eastern Europe: An introduction. Geographia Polonica, 91 (1), 5-16. https://doi.org/10.7163/GPol.0106

Kopciała, J. (ed.) (2000a). Kanał Augustowski: od Biebrzy do Niemna. Augustów-Suwałki: Wydawnictwo Hańcza.

Kopciała, J. (ed.) (2000b). Kanał Augustowski: Szlak wodny Euroregionu Niemen. Augustów-Suwałki: Urząd Miejski, „Hańcza”.

Kowalczyk, A. (2014). The phenomenology of tourism space. Turyzm/Tourism, 24 (1), 9-15. https://doi.org/10.2478/ tour-2014-0001

Kowalewska, P., Słoma, A. (2015). Euroregion Niemen jako przykład współpracy transgranicznej. In: J. Grabowiecki (ed.) Wspótpraca transgraniczna na wschodnim pograniczu Polski (pp. 145-153). Białystok: Wydawnictwo Uniwersytetu w Białymstoku.

Kudžmaitè, G. (2019). Before, during and after crossing the border: Narrating the 'visa-free Grodno'. Visual Studies. 34 (2), 148-163. https://doi.org/10.1080/1472586X.2019.1654910

Kul-Sialverstava, S. (2014). Pamięć historyczna mieszkańców pogranicza białorusko-polskiego. In: K. Snarski, A. Żulpa (eds), W krainie wielu tradycji. Badania etnograficzne na pograniczu polsko-litewsko-białoruskim w XX i początkach XXI wieku (pp. 120-136). Suwałki: Wydawnictwo Muzeum Okręgowego w Suwałkach.

Lenart, W. (2008). Zakres możliwej transgranicznej współpracy Białorusi, Litwy, Polski, Rosji i Ukrainy w dziedzinie gospodarki przestrzennej, zrównoważonego rozwoju oraz promocji regionalnej z uwzględnieniem założeń zielonych płuc Europy i ze szczególnym uwzględnieniem Kanału Augustowskiego. In: L. Witold, A. Zelenkov, Kanat Augustowski i wspótczesna ekoturystyka (pp. 277-295 ). Pułtusk-Mińsk-Grodno: Akademia Humanistyczna im. Aleksandra Gieysztora w Pułtusku.

Marin, A. (2011). From breach to bridge: The Augustów Canal, an ecotourism destination across the EU's border with Belarus. Articulo. Retrieved from: https://journals.openedition.org/articulo/1705 (10.06.2020). https://doi.org/10.4000/articulo.1705

Marin, A. (2017). Of barriers, breaches and bridges. Cross-border ecotourism and the prospect of horizontal governance acting as a bridge in Belarus-EU neighbourhood relations. In: I. Liikanen, J.W. Scott, T. Sotkasiira (eds), The EU's Eastern neighbourhood. Migration, borders and regional stability (pp. 115133). London-New York: Routledge.

Otwierajac białoruskie pogranicze. Kanał Augustowski i Grodno (2018). Grodno: Centrum Informacji turystycznej w Grodnie.

Pogranicze białoruskie do wypoczynku i podróży. Kanał Augustowski $i$ Grodno (2018). Grodno: Centrum Informacji turystycznej w Grodnie.

Pozlevich, T. (ed.) (2016). Augustovski Channel/Kanat Augustowski. Minsk: PrestigeIzdatReklama.

Roman, A., Sawośko, K., Żendzian, J., Niesteruk, P. (2018). Motywy podróżowania na pograniczu polsko-białoruskim. In: S. Sialverstava, A. Roman, J. Zuzda (eds), Promocja turystyki na pograniczu polsko-białoruskim (s. 171-188). Białystok: Wydawnictwo Niepublicznej Placówki Doskonalenia Nauczycieli „Edukacja, Wychowanie i Bezpieczeństwo” przy Towarzystwie Zapobiegania Tonięciom i Ratowania Tonących w Białymstoku.

Romanowa, O.S., Szirokowa, V.A., Ozierowa, N.A., Czesnow, V.M., Sobisiewicz, A.V. (2018). Augustow Canal as the monument of hydraulics and the objects of heritage tourism. Acta Geographica Silesiana, 12/3 (31), 37-44.

Rutkowski, M. (2017). Water canal system in projects, activities and reports of Polish authorities in the 1830s-1860s. Scientific Journal of Silesian University of Technology. Series Transport, 94, 211-227. https://doi.org/10.20858/sjsutst.2017.94.19

Sialverstava, S., Bogusz, T. (2018). Szlaki turystyczne w województwie podlaskim. In: S. Sialverstava, A. Roman, J. Zuzda (eds), Promocja turystyki na pograniczu polsko-białoruskim (pp. 121-134). Białystok: Wydawnictwo Niepublicznej Placówki Doskonalenia Nauczycieli „Edukacja, Wychowanie i Bezpieczeństwo" przy Towarzystwie Zapobiegania Tonięciom i Ratowania Tonących w Białymstoku.

Sialverstava, S., Bogusz, T., Roman, M. (2018). Tourism development in the Belarusian part of the Augustow Canal. Turystyka i Rozwój Regionalny, 9, 63-70. https://doi.org/10.22630/ TIRR.2018.9.7

Stasiak, A., Włodarczyk, B. (2008). Transgraniczne produkty turystyczne. In: Transkordonne spìvrobitnictvo âk faktor aktivizacii êvroìntegracijnich procesiv, Materiali XVII Mižnarodnoï naukovopraktičnoï konferenciï (pp. 336-338). Černìvcì 6-7 travnâ 2008 roku.

Stoffelen, A., Ioannides, D., Vanneste D. (2017). Obstacles to achieving cross-border tourism governance: A multi-scalar approach focusing on the German-Czech borderlands. Annals of Tourism Research, 64, 126-138. https://doi.org/10.1016/j. annals.2017.03.003

Suliga, J. (1996). Polsko-białoruska współpraca przygraniczna w dziedzinie planowania przestrzennego. In: A. Miszczuk, R. Wiśniewski (eds), Informacyjno-infrastrukturalne uwarunkowania wspótpracy transgranicznej. Vol. 2 (pp. 89-92). Lublin: Norbertinum.

Tourist Passport (2018). Białystok: Augustvelo.

Więckowski, M. (2010a). Specific features of development of tourism within the areas neighbouring upon the Polish Eastern 
border, European Union external and internal borders - interactions and networks. Europa XXI, 20, 101-115. https://doi. org/10.7163/Eu21.2010.20.8

Więckowski, M. (2010b). Tourism development in the borderlands of Poland. Geographia Polonica, 83 (2), 67-81. https://doi. org/10.7163/GPol.2010.2.5

Więckowski, M. (2014). Tourism space: An attempt at a fresh look. Turyzm/Tourism, 24 (1), 17-24. https://doi.org/10.2478/tour-2014-0002

Więckowski, M., Cyargeenka, A. (2019). Wpływ złagodzenia reżimu granicznego na Białorusi na wielkość ruchu turystycznego - wstęp do badań. Przegląd Geograficzny, 91 (4), 589-608. https://doi.org/10.7163/PrzG.2019.4.8
Włodarczyk, B. (2014). Space in tourism, tourism in space: on the need for definition, delimitation and classification. Turyzm/ Tourism, 24 (1), 25-34. https://doi.org/10.2478/tour-2014-0003 Yeliseyeu, A. (2017). Die neue Visaregelung. Langsam und mit Einschränkungen öffnet sich Belarus Reisenden aus dem Westen. Belarus-Analysen, 32, 2-6. https://doi.org/10.31205/ BA.032.01

Zichner, H., Beurskens, K., Miggelbrink, J., Bruns, B. (2017). Vor, an und hinter der Grenzlinie - Praktiken von Kontrollierenden und Kontrollierten. In: J. Miggelbrink (ed.), Grenze aushandeln: eine Untersuchung zur östlichen Schengengrenze 2007-2009 (pp. 116-121). Leipzig: Leibniz-Institut für Länderkunde. 